\title{
Management Problems Faced by Privately-owned Express Enterprises and the Countermeasures
}

\author{
Hongshou Chen
}

Huizhou Economics and Polytechnic College, Huizhou, Guangdong Province, China.

Keywords: private express; industry dilemma; development strategy.

\begin{abstract}
In recent years, with the increasing volume of Internet transactions, a large amount of private capital has flowed into express companies; the private express industry has developed rapidly and become a key component in China's express industry. But in the meantime, the private express industry is facing dilemmas. Privately-owned express enterprises need to address management problems in order to achieve sustainable development. These problems include, how to cope with competitions in the same trade, how to formulate enterprise strategies quickly, how to expand competitive advantages and how to improve the internal management system.
\end{abstract}

\section{Introduction}

Thanks to the sustained and rapid growth of national economy and the increasing volume of Internet transactions, the logistics industry and modern express delivery industry are booming in China. Especially in the retail service sector, the express delivery industry has entered a new stage of development in terms of openness and competitiveness. Attracted by the huge benefits of Chinese market, new players have entered the express delivery industry. On one hand, foreign capital has already targeted the Chinese market with huge consumption potential. On the other hand, the standard and self-discipline levels of the express delivery industry are constantly improving; a number of private express enterprises which are lack of service awareness and standard operations need to exit the market. How to enlarge and strengthen these privately owned delivery enterprises? It requires not only comprehensive understanding on the current situation of China's express delivery market, but also clear understanding on the conditions of privately owned express enterprises. Only in this way, can these companies further establish their own competitive advantages, which will be the key and focus for them to achieve further development.

\section{Development Situation of Privately Owned Express Companies in China}

The development process of privately owned express companies. Under the background of contradiction between increasing Internet transactions and inadequate logistics distribution ability, privately owned express enterprises enter the market as an effective social supplement. They help China's commercial industry to develop and enter a new era. At the same time, citizens have new expectations for express service. Modern express services come into being to meet people's new demands. With the implementation of the reform and opening up policy in 1978, the Express Mail Service Company (EMS) emerged as the times require and became the first express delivery enterprise of China. In 1990s, China's economy entered a period of rapid development, which led to the rapid expansion of express market. In this context, a number of privately owned express enterprises were established and rapidly developed. Until now, these privately owned enterprises have consolidated their positions in the huge Chinese market and become an important part of China's express industry.

The development scales of privately owned express companies in China. In recent years, the express delivery industry in China has achieved rapid growth. Domestic privately owned express enterprises spring up like mushrooms after rain. According to statistics data released by the State Post 
Bureau, by the end of 2016, express enterprises in China have delivered 31.28 billion packages; the express delivery revenue reached 397.44 billion yuan. Among them, privately owned express companies have delivered 28.24 billion packages and realized the business income of 332.88 billion yuan. Privately owned enterprises accounted for $90.3 \%$ of the industry with the market share of business income of $83.8 \%$. Privately owned express companies have become an important part of China's express delivery industry.

\section{Problems Encountered by Privately Owned Express Companies in China}

\subsection{Lack of high quality logistics professionals}

The lacking of logistics professionals restricts the development of Chinese express industry to a large extent. At present, most privately owned express enterprises hire relatively low-cost employees as the main labor force, and do not pay attention to the introduction and training of talents. The main performances are as follows. First, the employee mobility levels of many privately owned express companies are high due to low professional skill requirements and unreasonable salary system. The long-term development of enterprises and the industry is limited. Secondly, most employees, as well as managers, are in low educational levels. They do not have strong service awareness or good service attitude. Thirdly, the professional ethics education is not standardized. In some privately owned express enterprises, the phenomena of mail theft and missing package are common, resulting in clients' dissatisfaction and complaints. The key reason of customer complain is the low professional ethics of employees. According to statistics, more than $80 \%$ of work faults can be avoided. In addition, these enterprises are lack of perfect talent training mechanism; the numbers of introduced high-quality professionals are not enough.

\subsection{Privately owned express companies need to improve brand awareness}

The brand popularity of privately owned express enterprises is relatively low both at home and abroad, since some companies do not pay attention to brand building and are lack of corporate culture. It is essential for a new enterprise to publicize itself through advertising in order to win market recognition. At present, among Chinese privately owned delivery enterprises, S.F. Express has the highest service satisfaction level, followed by ZTO Express, YTO Express, STO Express, BEST Express and Yunda Express. Other privately owned express enterprises have no reputation.

\subsection{Less coverage of service outlets; no express service in the countryside}

At present in China, many privately owned express enterprises are relatively small in scale; outlets set up in the connection of express delivery are not enough. Most enterprises choose to construct their service outlets in county towns (or townships). There is service outlet in some remote villages; customers cannot enjoy the express service. These phenomena lead to poor customer evaluation on privately owned delivery enterprises.

\subsection{Fierce competition in the industry}

The competition between express companies is very fierce. First, privately owned express companies have to meet the competition from local state-owned express enterprises (EMS). EMS is the largest delivery enterprise in China; competition at varying degrees cannot be avoided in the city-wide, nonlocal and international express markets. Secondly, private delivery enterprises are under the impacts of international express giants. The gaps between foreign and domestic privately owned express enterprises are big in network construction, technology, personnel training and other aspects. The four express giants from foreign countries have occupied a certain share in the Chinese market by virtue of their strong financial capacities, perfect management systems, advanced equipments and technologies as well as the well-established brand reputation. Especially in the market of international express business, they have absolute advantages over domestic private companies and bring tremendous threat to the development of privately owned delivery enterprises in 
China.

\section{Countermeasures to Promote the Development of Privately Owned Express Companies}

\subsection{Improving the quality of employees}

The behaviors of employees represent the image of the company. To enhance the image of the enterprise, it is necessary to improve the overall quality of employees. Firstly, the employee training should be strengthened to form a complete set of behavioral norms, including their actions, appearance, choice of words, tones and even walking postures. Secondly, the company needs to improve the welfare of employees, in order to minimize their worries and improve their working efficiency as well as service awareness. After strict training, unreasonable phenomena such as violent throwing of packages can be effectively avoided. Thirdly, education on professional ethics should also be strengthened. The operation of express business should be standardized in accordance with relevant laws and regulations. Some packages need to be opened for inspection, so as to effectively stop illegal acts and criminal activities.

\subsection{Attach importance to the investment and cultivation of logistics professionals}

In the 21st century, talent competition can represent the market competition of enterprises to a certain extent. In this sense, privately owned express enterprises are in the position of disadvantage in the severe market competition, since they are lack of logistics professionals. Therefore, considering from the perspective of market competition, privately owned delivery enterprises should introduce talents who have received professional education or higher education, build a talent pool of managers and establish a practitioner training and cultivating mechanism.

\subsection{Improve service quality and expand brand awareness}

In the development of delivery enterprises, service qualities and brands are mutually influenced. Especially for privately owned express companies, in order to gain advantages in market competition, it is necessary for them to build brands with their own characteristics. Thus, the primary task is to avoid single enterprise publicity and low-price competition; express enterprises need to integrate resources and find their own advantages, such as rapid and efficient delivery or high-quality service. Then the company can build a unique brand on that basis, and constantly upgrades the brand and improve the internal strength of the company. In addition, a service quality evaluation system on private express enterprises can be established to accept the supervision from customers and the society. Social evaluation is useful in business development. Through these measures, the company can expand its market awareness and establish enterprises brand, then grow bigger and stronger.

\subsection{Construct more outlets and explore rural market}

In the early of 2016, the No.1 Central Document issued under the title of Some Opinions of the State Council of the CPC Central Committee on Applying the New Concept of Development and Accelerating the Modernization of Agriculture to Achieve the Goal of Building a Well-off Society in All Respects. The Article 14 of this document clearly states that the project of offering package delivery service in countryside should be launched; agricultural product markets and circulation facilities should be constructed; logistics service network and facilities should be constructed and connected to accelerate the improvement of logistics system in countryside, townships and villages. With the deepening of the "last kilometer" project and the rapid growth of rural consumption market, privately owned express enterprises should closely follow the government in constructing rural networks, trying to form a large-scale express network and solve the problem of "no express service in the last kilometer". At first, companies can look for cooperative agents to set up express delivery outlets to achieve the effective network coverage and solve the problem of high cost in rural network construction. Afterwards, from the perspective of sustainable development of enterprises, privately owned express enterprises should build their own service networks in villages and towns and open 
village-to-village express routes, so as to effectively improve the delivery capacity.

\subsection{Promote jointly cooperation among enterprises to enhance the overall competitiveness}

At present in China, many residents including rural residents prefer to choose online shopping. In the future express market, online shopping will be one of the most powerful income guarantees. The development space brought by online shopping is a development opportunity for privately owned express enterprises. First of all, private delivery companies should further strengthen e-commerce cooperation through resource integration and advantage complementary. As an effective complement of marketing, E-commerce can not only promote the rapid development of the express industry, but also improve the satisfaction levels of customers on express service. Therefore, private express companies should closely cooperate with each other, make use of their strengths and complement their weaknesses, so as to achieve the win-win result. Secondly, functional departments of the government should promote the establishment of industry regulations and standards, in order build an "orderly competitive express market which provides convenient, efficient and high-quality services", and enhance the overall competitiveness of privately owned express enterprises.

\section{Conclusions}

Through above analysis, it is found that factors affecting the development of privately owned express enterprises can be concluded as two main problems. One is the self-positioning problem. Privately owned express enterprises in China are satisfied with current status and do not face up to future development space. Main manifestations are small scales, backward technology, lack of professionals and management system, narrow business scope and small business areas. The other problem is market competition. With the sustained development of China's economy and the internationalization of express market, international express giants have seized the opportunity and entered Chinese market, which inevitably brings challenges to the growth and development of privately owned express enterprises. The combination of these two factors charted the development course of domestic private express companies. In order to remain invincible in the future, privately owned express enterprises should constantly make up their shortcomings through actively introducing talents and information technology, accelerating the improvement of express service quality and efficiency, and trying to win the trust of consumers. In addition, they must seize policy opportunities and open up new rural markets to expand business scope.

In short, in the face of challenges, China's privately owned express enterprises should recognize the reality, give full play to their competitive advantages, overcome shortcomings and improve service qualities. In the future, these companies will occupy more market shares and play a more important role.

\section{References}

[1] Y. Wang, Y.Q. Li, Problems faced by private express enterprises under the new situation and countermeasures, J. Jiangsu Commercial Forum. 7 (2018).

[2] State Post Bureau of PRC, The Performance of the Post Industry in 2016 [EB/OL]. [2017-01-14]. http://www.spb.gov.cn/xw/dtxx_15079/201701/t20170114_959038.html.

[3] H.Y. Li, Will express industry usher in the turning point, J. People's Weekly. 5 (2017).

[4] Q.J. Liao, Development status, existing problems and development strategy of privately owned express enterprises in China, J. Logistics Technology. 11 (2017).

[5] Y.F. Wu, The future development of privately owned express enterprises: analysis from the match between Green hand and S.F. Express, J. Practice in Foreign Economic Relations and Trade. 9 (2017). 